Eggers 10 例, 腱切り 3 例を行なつた。 下腿内捻に対 しては骨切り術 1 例を行ない，尖足矯正には，筋膜切 開を主体とし 52 例に行ない, 腱延長 18 例, Stoffel 11 例を行なつた。 内反足に対しては，前脛骨筋また は後脛骨筋の腱移行をまず試み 11 例に行ない，腱延 長 5 例，関節固定術 2 例を行なつた．趾屈曲拘縮に対 しては, 筋膜切開 8 例, 腱切り 11 例, 腱延長 6 例, 骨切り 1例を行なつた。

\section{結語}

C P 児汇対する過去 5 年間の手術内容を，病型，年 令, 術式等の上加ら検討し, その手術適応をのへ，適 応あれば，早期に手術を行なうととの要を報告した。

\section{参 考 文 献}

1) Baker, L. D. J.: Bone and Joint Surg. 46-A : 1-14, 1964.

2) Samilson, R. L.: J. Bone and Joini Surg. 46A : 1203-1216, 1964.

3) Eggers, G. W. N.: J. Bone and Joint Surg. 45-A : 1275-1305, 1963.

4) Pollock, G. A.: J. Bone and Joint Surg. 44B : 68-81, 1962.

5) Nilsonne, H.: Acta orthop. scand. 32:334337, 1962.

6) Eggers, G. W. N.: J. Bone and Joint surg. 34-A : 827-830, 1952.

7) 寺沢：日整会誌。 $37: 766$, 昭 38 ,

8）志賀：日整会誌. $37: 807$, 昭 38 .

9）小池：日整会誌。 $35: 919$, 昭36,

10）玉置：日整会誌. $33: 1028$, 昭 34 .
発 言

㕕大 津 下

指間固定術を相当しておられるが，手術適応の判定 は難かしいと思われるが。

答

佐賀整肢園 多田 俊 作

骨関節に対する手術は矢張り，二次的で，まず abductor pollicis 飞腱移行を試み,目的を達し得ない 時は，指間固定術を行ないます。

発言熊大 玉 井

$\mathrm{O} P$ 後の再発はどの位ありますか.

答 佐賀整肢園 多田 俊 作

例えば，下腿の筋膜ですが， $2 \sim 3$ 年後に再発を示 すCase が多いようにあります，当園では，夜間シ 一ネを使用していますが，なお再発例佉対し，2 次的 に 10 才頃に再矯正を行なつています.

$$
\text { 発言広大津 下 }
$$

上肢痙性麻㾝に 対する手術は慎重でなければなら ず，好結果を期待し得る確信ある時のみ手術を行なう ようにする，関節固定術は最後の手段で出来得るだけ 腱移行術で処置するのが良いのではないか.

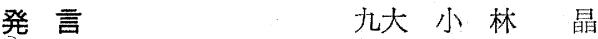

どのような type に主として tendon transfer の 適応があると扔考えですか.

$$
\text { 答広大津年 }
$$

Hemispastishe type のみに行なう。

\section{発言長大玉置拓夫}

$\mathrm{CP}$ ○の手の外科の適応は極めて 少ないと考元る が，年長児で IQ の良いあのでは劣等感を 取り除く 意味で外観の改善を行なう。

\title{
別府整肢園における $\mathrm{CP}$ 機能訓練の検討
}

$\begin{array}{ccccc}\text { 別府整肢 園 } & & & \\ \text { 中 村 } & \text { 裕 畑思和 男 } \\ \text { 碓井良弘和 } \text { 田 } & \text { 宏 }\end{array}$

\section{Consideration of C. P. Rehabilitation.}

By

\author{
Y. Nakamura, K. Hatada, Y. Usui and H. Wada \\ Beppu Cripple Children Center.
}

近年産科技術，未熟児育児の進歩，ポリオワクチン の普及, 抗生物質の進歩とともに, 肢体不自由児施設
におけるC P の増加が著明であるととはたびたびいわ れている. 我々の整肢園でも， C P の占める比率は約 
半数に達し，C P の治療にまとあに取組まねばならな くなつている. C P の治療の基本は機能訓練にあり, 手術, 薬物等は補助的手段にしか過ざないというとと は多くの権威者のいうとてろである，そこで，その機 能訓練を行なうに当つて, 我々が日頃痛切沘じてい る問題を提示し，機能訓練の検討を行なつてみたい。 あえて第一に上げたい問題は，機能訓練に対する診療 報酬があまりに安過ぎるということである，C P の訓 練は原則として，1対 1 のマット訓練にあり，最低 30 分は必要である. 患者運般, 準備, 介助を含める之 50 分程も時間を要するし，1 人のセラピストが一日に 行なえる人数は, 自づと10人内外でしかない。乙の報 酬は 1 人 60 円合計 600 円にしかならないのである. C P の場合， P T, OT，水治療法む行なつている が，どれだけやつてあ報酬は同じである，我々の施設 は独立採算であり，その上一般病院にはいない生活指 導員, 保母等まで必要であるから, 採算を度外視した
セラピストの増員は不可能である。したがつて, 現有 スタッフで最大の効果を上げるには，能率的なシステ ムを作り，治療目標を適当にしばるより他はない，整 肢園では学校, 幼稚園, 検温, おやつ, 回診, カンフ アレンス等の時間との関係があり，能率的な時間編成 はむづかしい問題の一つである. 表 1 は昭和 39 年 12 月 まで行なわれていた訓練時間表である。乙れでは 40 分 の時間に平均 36 人が一度に押しかけ, 障碍のひどい 子は訓練棟への出入りに多くの時間を費し, 元気の上 い LCC, ポリオの PRE, 歩行練習が訓練の 主体であ つた. そこで昭和 40 年 1 月より表 2 のカッコ内のC P を重点的に訓練を行ない，午後曐基本訓練に主力を入 れた。現在は再度反省を加え，表 3 のような時間編成 を行なつている，次に治療目標を，歩けない子が歩け るように, selfcare のできない子に，最低限の selfcare 能をつけてやるととに置き， その目標の対称と なる障碍のひどい子供を重点的に訓練して，それ以上

表 1 訓練 時間及び肉容その 1

39. 12. 31 まで

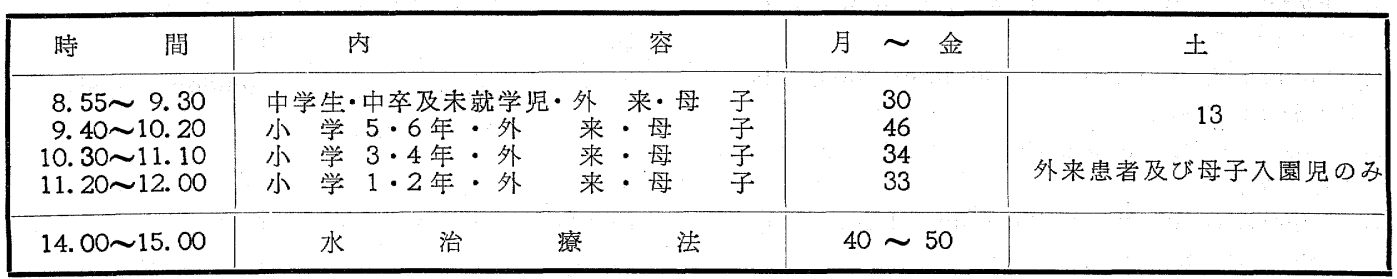

表 2 訓 練 時間 及び内容その 2

40. 5.1 より

\begin{tabular}{|c|c|c|c|c|c|c|}
\hline 間 & \multicolumn{2}{|c|}{ 内 } & \multicolumn{2}{|c|}{ 容 } & 月 $\sim$ 金 & \pm \\
\hline $\begin{array}{r}9.00 \sim 11.00 \\
11.00 \sim 12.00\end{array}$ & \multicolumn{4}{|c|}{$\begin{array}{l}\text { 未就学園児・中学卒業園児病室訓練・母子入園児 } \\
\text { 外来 }\end{array}$} & $\begin{array}{ll}20 & (11) \\
32 & (15)\end{array}$ & $\begin{array}{l}11(11) \\
\text { 外来患者及び母子入園児 } \\
\text { のみ }\end{array}$ \\
\hline $13.00 \sim 17.00$ & 全 & 小 & 学 & 生 & 91 (45) & \\
\hline
\end{tabular}

註（）はC．P.児のマット訓練（基本訓練）を示す.

火. 水の 11. 10 12.00 水治療法 10 15 名施行.

表 3 訓練 時間及び内容その 3

44. $1.1 \sim 4.30$

\begin{tabular}{|c|c|c|c|}
\hline 間 & 内 & 月 $\sim$ 金 & \pm \\
\hline $\begin{array}{r}8.55 \sim 9.30 \\
9.40 \sim 10.20 \\
10.30 \sim 11.10 \\
11.20 \sim 12.00\end{array}$ & 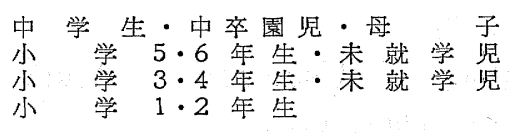 & $\begin{array}{l}36 \\
47 \quad(11) \\
31 \\
32 \quad(10)\end{array}$ & $\begin{array}{c}10(10) \\
\text { 外来患者及母子入園児のみ }\end{array}$ \\
\hline $\begin{array}{l}13.00 \sim 14.00 \\
14.10 \sim 16.00\end{array}$ & 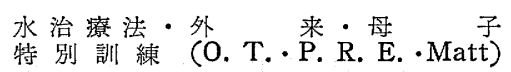 & $\begin{array}{l}12 \sim 20 \\
28(7)\end{array}$ & \\
\hline
\end{tabular}

註（）はC．P.児のマット訓練（基本訓練）を示す. 
の機能のある者には，スポーティーなグループ訓練を 行なつた.上下肢之あ障碍の強い者には，移動動作 の解決を優先させた. 表 4 はその治療方法である. developmental training は表 5 の順序で行なつた. C P の機能訓練は運動発達段階にそつて, 順序正し く，一歩一歩リハビリテーションを行なうととが基本 となることは諸家共通していうととろであるが, 我々 は目標である独立歩行に最短距離で到達するために, 稫幹筋, 抗重力筋の筋力強化には特に力を入れ, 運動 発達段階を飛び越えて先へ進ませることあ積極的に試 みた。 また独立歩行の一手段として,ブレース,クラッ チの使用む積極的により上げた. PNF, PIP, ルード の方法等の特殊な方法もケースバイケースで採用し た. しかし RIP をアテトーゼの訓練前段階としての リラクセーションのために用いる以外は，あまり積極 的にはやらなかつた．評価基準は運動年令の明らかな 進歩のあつたあのを 3 ，わずかであ進歩のあつたもの を 2 ，不変 1 ，悪化 0 とした．また訓練度合によつて 進歩がどのように違つてくるかを見るために，訓練度 合も評価した．即ち，ほとんど休まずやつたあの 3 ， 時々休んだあの 2 , 休みがちのもの1, 活とん゙やら なかつたすの0とした，成績を年令別に分けてみると 表 7 の如くで, これは表 8 で分るように，8才までの 子亡，9才以上の子では，その成績に明らかな差があ ることが分る．即ち運動年令の明らかな進歩のあつた あのは，8才以下では 13 人中 7 人 $53.8 \%$ あつたの に対し，9才以上では 26 人中 2 人 $7.9 \%$ 的みられ なかつた。ささらてれを効果のあつた群と無かつた群
表 4 Treatment Method

\begin{tabular}{|ll|}
\hline 1 & developmental training \\
2 & balance \\
3 & relaxation \\
4 & muscle training \\
5 & mobilization of joint \\
6 & special technique \\
7 & O. T. \\
8 & brace \\
9 & Water treatment \\
\hline
\end{tabular}

表 5 Developmenhal Training
Head Control
Reciprocation
Rolling
Sitting Balance
Tailar Sitting
Sitting on Knee
Long Sitting
Knee Chest Position
Crawling
Kneeling
Kneeling on one Foot
Standing up
Stand Balance
Walking With ald

表 6 Special Technique

\begin{tabular}{|ll|}
\hline 1 & R. I. P. (Bobath) \\
2 & P. N. F. (Kabat) \\
3 & Revelsal Antagonist \\
4 & Rhythmical Stabilization \\
5 & Rood's Method \\
6 & T. N. R. \\
7 & T. L. R. \\
8 & Yamamoto's Method \\
\hline
\end{tabular}

表 $\quad 7$

\begin{tabular}{|c|c|c|c|c|c|c|c|c|c|c|c|}
\hline \multicolumn{6}{|c|}{ Spastic } & \multicolumn{6}{|c|}{ Athetoid } \\
\hline $\begin{array}{l}\text { 評価 } \\
\text { 年令 }\end{array}$ & 3 & 2 & 1 & 0 & 計 & \begin{tabular}{|c|} 
評価 $^{\text {年令 }^{-1}}$ \\
\end{tabular} & 3 & 2 & 1 & 0 & 計 \\
\hline $\begin{array}{r}5 \\
6 \\
7 \\
8 \\
9 \\
10 \\
11 \\
12 \\
13 \\
14 \\
15 \\
16 \\
17\end{array}$ & $\begin{array}{l}1 \\
2 \\
2 \\
1 \\
1\end{array}$ & $\begin{array}{l}2 \\
1 \\
1 \\
1\end{array}$ & $\begin{array}{l}1 \\
2 \\
2 \\
1\end{array}$ & 1 & $\begin{array}{l}1 \\
4 \\
3 \\
\\
3 \\
1 \\
2 \\
1 \\
3 \\
\end{array}$ & $\begin{array}{r}5 \\
6 \\
7 \\
8 \\
9 \\
10 \\
11 \\
12 \\
13 \\
14 \\
15 \\
16 \\
17\end{array}$ & $\begin{array}{l}1 \\
1\end{array}$ & 2 & $\begin{array}{l}1 \\
3 \\
1 \\
2 \\
\\
2 \\
2 \\
1\end{array}$ & & $\begin{array}{l}2 \\
2 \\
1 \\
3 \\
1 \\
4 \\
1 \\
1 \\
2 \\
2 \\
1\end{array}$ \\
\hline 計 & 7 & 5 & 6 & $\mathbf{1}$ & 19 & 計 & 2 & 6 & 12 & $\mathbf{0}$ & 20 \\
\hline
\end{tabular}


表 8

\begin{tabular}{|c|c|c|c|c|c|c|c|c|c|c|c|c|c|c|}
\hline 評 & 価 & \multicolumn{3}{|c|}{3} & \multicolumn{3}{|c|}{2} & \multicolumn{3}{|c|}{1} & \multicolumn{3}{|c|}{0} & \multirow{2}{*}{ 計 } \\
\hline & 型 & $S$ & A & 計 & $S$ & A & 計 & $S$ & A & 計 & $S$ & $A$ & 計 & \\
\hline $\begin{array}{l}5 \\
9\end{array}$ & $\begin{array}{c}\sim \\
\sim 17\end{array}$ & $\begin{array}{l}5 \\
2\end{array}$ & 0 & 2 & $\begin{array}{l}2 \\
3\end{array}$ & $\begin{array}{l}2 \\
4\end{array}$ & $\begin{array}{l}4 \\
7\end{array}$ & $\begin{array}{l}1 \\
5\end{array}$ & $\begin{array}{r}1 \\
11\end{array}$ & $\begin{array}{r}2 \\
16\end{array}$ & 1 & $\begin{array}{l}0 \\
0\end{array}$ & $\begin{array}{l}\mathbf{0} \\
\mathbf{1}\end{array}$ & $\begin{array}{l}13 \\
26\end{array}$ \\
\hline & 計 & 7 & 2 & 9 & 5 & 6 & 11 & 6 & 12 & 18 & 1 & 0 & 1 & 39 \\
\hline
\end{tabular}

に二分してみると一層明らかで，8才以下のあのは実 に $84.6 \%$ 飞進歩がみられているのに，9才以上では $34.6 \%$ 亿とどまつて拈り，約 $2 / 3$ は効果がみられなか つたてとになる。 では訓練度合がその訓練効果代如何 倞響するかをみてみると，訓練をほとんどやらなか つたあの，休みながらのむの 5 人総て進歩がみられ ず，乙れに比へ，訓練を時々しか休まなかつた者は 34 人中 20 人約 $60 \%$ 亿進歩がみられた。 また明らかに 運動年令の進歩したむの 9 人中 7 が，ほ亡んど休まず 訓練を受けているととは注目すべきてとである．次に タイプよる差をみてみると, 評価 3 を得た 9 人の中 7 人までが痤直型で, とにかく進歩のあつた者 20 人中 12 人が病直型で, 明らかに痙直型の方が良好な成績を 上げている. また痙直型 19 人の成績をみてみると, 評洒 3 を得たものが 7 人 $36.8 \%$ ，評価 3 と 2 を合計 した数は 12 人で $63 \%$ であつた. これに対してアテ トーゼでは, 評価 3 を得た者は 20 人中 2 人, 評価 3 と 2 の合計む 8 人で $40 \%$ にとどまつている. 型別の 評価をさらに年令別にみると, 表 9 のように，9才以 上のアテトーゼでは実に 15 人中 11 人， $73.3 \%$ 亿何 ら効果が無かつたととは注目しなければならない，長 下肢装具を痙直型 6 例，アテトーゼ 3 例使用した が, 痤直型では全例評価 3 , アテトーゼでは評価 2 が 2 例, 評洒 1 が 1 例だつた. 以上のような成績から 9 才以上，特にアテトーゼの機能訓練の方法には検討を 加える必要を感じ, 最近我々は同程度の患者を $2 つ の$

表 $99 \sim 17$ 才

\begin{tabular}{|l|c|c|c|c|c|}
\hline & 人数 & 有効 & 無効 & 有效 & \multicolumn{1}{c|}{ 無効 } \\
\hline spastic & 11 & 5 & 6 & 45.4 & 54.6 \\
athetoid & 15 & 4 & 11 & 26.7 & 73.3 \\
\hline
\end{tabular}

グループに分けて，一方には今まで通りの方法を継続 させ, 他の一方では, 運動発達段階のあらゆる運動動 作を充分マスターするまで，その段階の運動を徹底的 に訓練させ，どちらが有効であるかを調べている，そ して次には機能訓練の限界を決める指標を確立し，い たづらにだらだらと無意味な訓練を続けるマイナスを 無くしなければならないと同時に，ADL の低い状態 で限界にきた子供達に, 医学的に社会的にどう対処す べきか, 我々は真剣に取組まねばならないと思う。

$$
\text { 摘 要 }
$$

我々は整肢園に扔いて C P の機能訓練を行なうに際 し, 医学以前の重要な問題として, 機能訓練の彰療報 酬の安さと, 訓練時間編成の問題について述べた.

次に機能訓練の臨床統計を行ない, 訓練勃果が 8 才

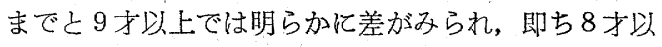
下では $84.6 \%$ に効果がみられたが，9才以上では $34.6 \%$ にとどまつた. 訓練度合による成績の影響で は, 最高の評価 3 を得たすの 9 人中 7 人までが充分訓 練を受けており，一方ほとんど訓練をしなかつた 5 人 全部が何ら進歩がみられなかつた，㾏直型とアテトー ゼ型と比べると, 痙直型の方が明らかに良好な成績を

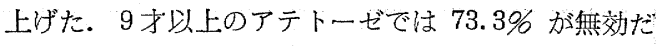
つた.

\section{発言九大天 䝨 \\ C P 児の手術に対ずる御意見は}

\section{答新光園 城戸 正 明}

部分的に見ると手術が相当な効果をあげる例があ る. しかし患児全体として，その知能，意欲等を全般 的に見なければならないが，今までのやり方では不充 分で, 最近手術的療法に積極的に乗り出している. 